\section{Galactose Metabolism : Phenotypic Differences among Tissues of a Patient with Congenital Galactosæmia}

IT has recontly been reported that two patients who had the characteristic syndrome of congenital galactosamia as infants, and who lack gal-1-P uridyl transferase in their red blood cells, are nevertheloss able to oxidize galactose-1-14 $\mathrm{C}$ to ${ }^{14} \mathrm{CO}$ in vivo in a noar-normal fushion ${ }^{1}$. It is therefore apparent that some tissues within these individuals must be capable of metabolizing galactose. Further studies on one of thoso subjects (T.B.), a 30-year-old Negro who was tho first case of galactosamia reported in the American literature ${ }^{2}$, have inquired into possible tissue differences with respect to the presence or absence of the metabolic derangemont typical of galactosæmia.

Five different tissues derivod from T. B. have been examined in vitro for their ability to metabolize galactose. The results obtained with white blood colls ${ }^{3}$ and skin cells in tissuo culture ${ }^{4}$ have beon reported proviously. These results, together with those obtained for hremolysates, intestinal mucosa and liver, are presented in Tablo 1. Of the tissues studied, only livor compares favourably with the normal in its ability to oxidizo galactose-1-14 $\mathrm{C}$ to ${ }^{14} \mathrm{CO}_{2}$. Thus it would appear that this caso ropresonts a situation in which marked differences exist among tissues of a galactosamic subject with respect to their galactoseoxidizing capacity relative to that of their normal counterparts. The implications of these observations in relation to galactose metabolism in vivo are not immediately apparent and deserve furthor study.

The pathway by which the liver of this galactosæmic patient is able to oxidize galactose deserves further consideration. Anderson et al. ${ }^{5}$ reported that liver obtained by noodle biopsy from the same patient had about 5 per cent of the normal ability to incorporate ${ }^{14} \mathrm{C}$-galactose-1-phosphate into uridine nucleotido in the presence of uridine diphosphoglucose and uridine triphosphate, a finding which indicated a marked

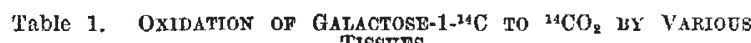
TISSERS

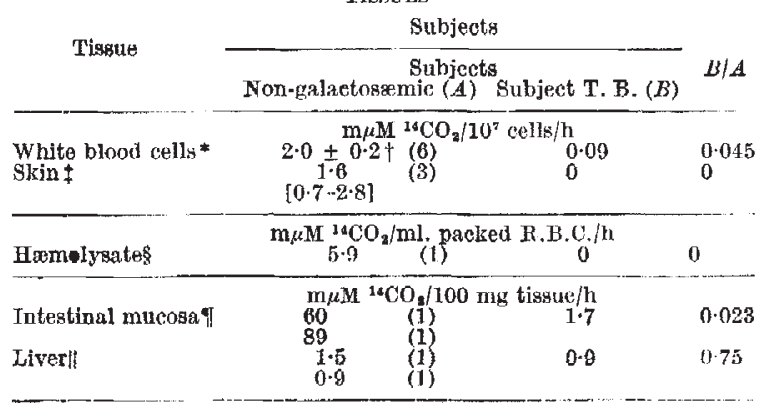

Nos. in parentheses refer to the No. of subjects.

* Data calculated from tho paper by Weinbers (ref, 3).

+ S.E.

Data calculated from the report of Krooth and Woinberg (ref. 4). A 20 per cent hæmolvsate was prepared by freezing and thawing R.R.C. suspended in K rebs phosphate buffer, $p \mathrm{H} \quad 7 \cdot 4$, after remova of W.B.C. by centrifugation. The incubation medium contrined $2 \mathrm{mi}$ of hæmolysate, $0 \cdot 1 \mu \mathrm{s}$. galactose-1-14 $\mathrm{C}(4.72 \mu \mathrm{c} / \mathrm{mg}), 1 \cdot 1 \mu \mathrm{M}$ ATT and $0.54 \mu \mathrm{M}$ 'TPN. ${ }^{10} \mathrm{CO}$, was collected as described previously (ref. 7 ) II Suction biopsy of the small intestine mucosa was performed perorally with the instrument described by Brandborg ot al. (ref. 8) and comparisons between normal and $T$. B, were made using tissue from the upper jejunum. $5 \mathrm{mg}$ pieces of tissue were incubated in $3 \mathrm{ml}$. of $\mathrm{K}$ rebs hicarborate buffer, $p \mathrm{H} 7 \cdot 4$, containing $0.15 \mu \mathrm{c}$. of radioactfy galactose, Each value represcnts the average of duplicata determinations.

II Liver biopsy of T. B. was nerformed with a Menghini neodle. The $15 \mathrm{mg}$ of tissue were cut into four segrrents and incubated as described for intestinal mucosa. One pices of tissue was boiled for 2 min before incubation and served as a blank. Liver binpsy of controls was obtainer at surgery from two individuals suffering from gall bladder diseaso. The surgical specimen was cut into $v-10 \mathrm{mg}$ reduction of transferase activity as well as of any related alternative pathway. Howover, the subject was capable of forming glucosiduronic acid from galactose at a normal rate ${ }^{6}$, an observation which is consistent with the present results obtained on the patient's liver and the in vivo results reported previously ${ }^{1}$. 'These findings can be explained on the basis that either the low activity dotectcd by Anderson et al. is sufficient to account for the results of the in vivo and present in vitro studies, or that the path. way of galactose motabolism in the liver of this subject differs from that of the normal.

The finding of definite phenotypic differences among soveral tissues from a single galactosæmic patient when studied for their ability to oxidize galactose in vitro indicatos that galactosremia is a moro complox diseaso ontity than has been appreciated hitherto.

\section{YALE J. TOPPER}

LEONARD LASTER Stanton SEgaL

National Institutes of Health, Bethesda, Maryland.

1 Segal, S., Blair, A., and Topper, Y. J., Science, 136, 150 (1962).

2 Mason, H. H., and Turner, M. E., Amer. J. Disease Children, 50, 358 (1988)

Weinberg, A. N., Metabolism, 10, 728 (1961).

- Krooth, R. S., and Weinberg, A. N., J. Exp. Med,, 118, 1155 (1961). Anderson, E. P., Kalckar, H. M,, and Isselbacher, K. J., Science, 125,113 (1957),

- Isselbacher, K, J., Amer. J, Med., 26, 715 (1959).

'Segal, S., Blair, A., and Weinberg, A. N., Metabolism, 9, 1033 (1960). Brandborg, L. L., Kubin, C. E., and Quinton, W. E., Gastroenterolomy. 87,1 (1959)

\section{Metaplasia of Aortic Connective Tissue to Cartilage and Bone induced by the Intravenous Injection of Papain}

T'HE effect of intravenous papain on the cartilage matrix has been reported by L. Thomas' ${ }^{1}$ Recently wo havo boon invostigating tho acute lipemia induced by the injection of papain solution in adult rabbits 2 . At the end of each experiment, the animals were killod by air embolism and autopsies were porformed. Several of these experimental animals showod lesions in the ascending aorta, and the arch, and to a lesser extent in the upper portion of tho doscending aorta. This communication deals with the description of these lesions and of the conditions under which they were developed.

Grossly, the lesions appeared woll delineated by a halo of raisod tissue with irregular surface and edges

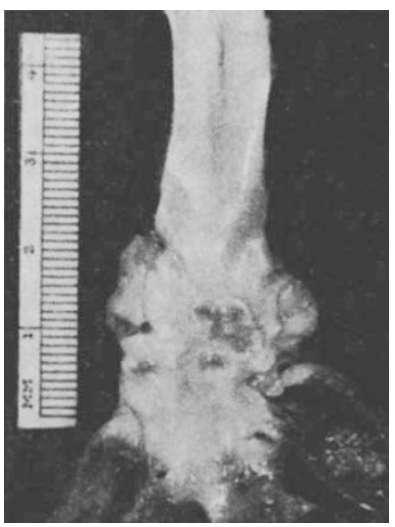

Fig. 1. Aorta of rabbit No. 89, male, $5,670 \mathrm{~g}$, injected once with 